\title{
A Case of Bicarbonate-losing Renal Tubular Acidosis with Defective Carboanhydrase Activity
}

\author{
R. A. DONCKERWOLCKE, G. J. VAN STEKELENBURG, and H. A. TIDDENS \\ From the Wilhelmina Kinderziekenhuis, University Children's Hospital, Utrecht, Netherlands
}

\begin{abstract}
Donckerwolcke, R. A., van Stekelenburg, G. J., and Tiddens, H. A. (1970). Archives of Disease in Childhood, 45, 769. A case of bicarbonatelosing renal tubular acidosis with defective carboanhydrase activity. A girl of 20 months had primary proximal renal tubular acidosis with a lowered renal threshold for bicarbonate. There was no carboanhydrase inhibition after acetazolamide administration, suggesting that defective carboanhydrase activity may have been causative.
\end{abstract}

Renal tubular acidosis (RTA) is classically defined as tubular insufficiency in renal excretion of $\mathrm{H}+$ ions, out of proportion to, or occurring in the absence of glomerular insufficiency (Elkinton $e t$ al., 1960). Rodriguez Soriano and co-workers have considerably expanded this concept; they differentiate between proximal RTA associated with a disturbance in reabsorption of $\mathrm{HCO}_{3}^{-}$, and a distal type associated with a defect in excretion of $\mathrm{H}+$. These defects can occur in combination, but will considerably exceed in importance any possibly associated glomerular disturbance (Rodriguez Soriano et al., 1967; Rodriguez Soriano and Edelmann, 1969). Morris (1969) prefers a classification on a physiopathological basis and suggests the terms 'rate type RTA' (bicarbonate wasting) and 'gradient type RTA' (impaired excretion of $\mathrm{H}+$ ).

Several reports have described conditions in which either a disturbance in reabsorption of $\mathrm{HCO}_{3}^{-}$, or in excretion of acid, constitutes one aspect of a complex clinical picture. These conditions are usually classified as secondary (Royer and Broyer, 1967; Rodriguez Soriano and Edelmann, 1969).

On the other hand there are the isolated disturbances of as yet obscure aetiology, which are referred to as primary (Rodriguez Soriano et al., 1967). Theoretical considerations and experimental findings (Rector et al., 1960; Schwartz, Falbriard, and Relman, 1958) suggest that such a disturbance may be based on renal carboanhydrase deficiency. The present study supports this hypothesis.

\section{Case Report}

The patient was born at term after an uneventful pregnancy and parturition; her birthweight was $3500 \mathrm{~g}$.

Received 31 March 1970.
She is the sixth child of non-consanguinous parents; the first child has cerebral palsy, and the third child a cleft palate. At 11 weeks she was admitted to hospital elsewhere for vomiting, diarrhoea, and a tendency to hypothermia; she was then noted to have a persistently low serum total $\mathrm{CO}_{2}(14 \mathrm{mEq} / \mathrm{l}$.).

At 20 months she was admitted for investigation of her retarded growth (Fig. 1). She was small and thin, both height and weight being well below the 3rd centile.

The musculature was hypotonic; reflexes were normal. Blood pressure, ECG, and chest $x$-ray were normal. Eyes: besides convergent squint, there was a bilateral band-keratopathy which progressed during the period of observation.

Griffith's IQ test at a chronological age of 127 weeks gave a mental age of 84 weeks and a general IQ of 66 .

Bone age 3 months (at age 20 months). Intravenous pyelography : renal size and excretion normal; no nephrocalcinosis.

Chromosomes (J. O. van Hemel) were normal.

\section{Methods}

The acid-base status in blood $\left(p \mathrm{H}, \mathrm{PcO}_{2}, \mathrm{HCO}_{3}^{-}\right.$, and total $\mathrm{CO}_{2}$ ) was determined by the Astrup method; $\mathrm{Na}$ and $\mathrm{K}$ by flame photometer; $\mathrm{Cl}$ colorimetrically, phosphate, creatinine, and insulin (anthrone method) colorimetrically; glucose by the glucose-oxidase method; $\mathrm{Ca}$ by visual titration with EGTA using ortho-OH-naphtholblue as indicator; urea by urease reaction in combination with indophenol reaction. Gastric acid secretion after histamine stimulation was measured during 3 consecutive 30-minute periods.

Urine $p H$ was measured with a $p H$ electrode; titrable acid by immediate titration to $p H \quad 7.4$ with $0.1 \mathrm{~N}$ $\mathrm{NaOH}$, ammonium content colorimetrically, using the indophenol reaction.

The total $\mathrm{CO}_{2}$ of the urine was determined by the method of van Slyke and Neill (1924) adapted by Mook (1930) using a microgasometer. The $\mathbf{P C O}_{2}$ and bicar- 


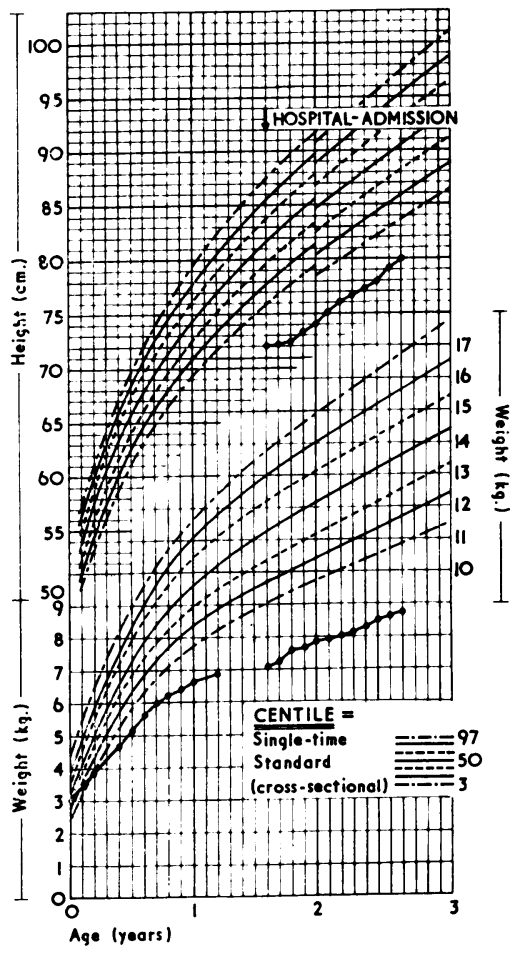

FIG. 1.-Growth rate.

bonate concentration were calculated from the Henderson-Hasselbach equation.

Amino acids were determined by column chromatography; osmolality by cryoscopy.

Maximal concentrating capacity was examined after thirsting (Edelmann et al., 1967a) and after vasopressin administration. Glucose reabsorption was measured by the method of Royer, Mathieu, and Habib (1963); GFR by endogenous creatinine clearance; and the renal contribution to acid-base regulation by the methods described by Edelmann et al. (1967b), with modifications to be discussed.

Urine collections employed an indwelling urethral catheter (urine was not collected under oil, since gases readily diffuse between urine and oil) (Oetliker and Rossi, 1969).

Acid loading test (Edelmann et al., 1967c). $\mathrm{NH}_{4} \mathrm{C1}$, $75 \mathrm{mEq} / \mathrm{m}^{2}$ was administered orally during a period of 60 minutes. Hourly urine collections were obtained before and during the 5 hours after $\mathrm{NH}_{4} \mathrm{Cl}$ administration, for determination of $p \mathrm{H}$, titrable acid (TA), and ammonium $\left(\mathrm{NH}_{4}^{+}\right)$. Arterialized blood samples were obtained before and 3 hours after acid load. From these data the hydrogen ion clearance index was calculated (Elkinton et al., 1960; Peonides, Levin, and Young, 1965). Hydrogen ion clearance index $=\mathrm{H}+$ excretion (mEq/ min. $\left./ 1 \cdot 73 \mathrm{~m}^{2}\right) \times$ plasma $\mathrm{CO}_{2}$ content $(\mathrm{mEq} / \mathrm{l}$.), where $\mathrm{H}_{4}^{+}$excretion $=\mathrm{TA}+\mathrm{NH}_{4}^{+}-\mathrm{HCO}_{3}^{-}$.
Bicarbonate titration. Bicarbonate reabsorption was investigated by the continuous infusion of a solution containing sodium bicarbonate, inulin, and $5 \%$ glucose. In the first study, bicarbonate threshold, tubular reabsorption, and the response to acetazolamide were examined (standardized or low flow method, Edelmann et al., 1967b). After control collections, bicarbonate was infused at a rate calculated to produce an increase in serum bicarbonate of $1.5 \mathrm{mEq} / \mathrm{l}$. per $\mathrm{hr}$. When the bicarbonate threshold was reached, as judged by increase in urine $p \mathrm{H}$ to between 6.5 and $7 \cdot 0$, the rate of bicarbonate infusion was increased by a factor of 3 (to 0.45 $\mathrm{mEq} / \mathrm{min}$. $\mathrm{NaHCO}_{3}$ ). Urine was collected at $30-$ minute intervals, at the midpoint of which blood samples were obtained from an indwelling needle that was flushed with slightly heparinized isotonic saline solution after each sampling. Over the entire range of serum $\mathrm{HCO}_{3}^{-}$, values for $\mathrm{HCO}_{3}^{-}$reabsorption and excretion were determined. After 6 hours of $\mathrm{Na}$ bicarbonate infusion, when serum $\mathrm{HCO}_{3}^{-}$had reached about $20 \mathrm{mEq} / 1$, acetazolamide in a single dose of $12.5 \mathrm{mg}$. $/ \mathrm{kg}$. was administered intravenously, and collections were continued for a further two 30-minute periods.

In a second study (high flow method), bicarbonate was infused at a rate of $0.45 \mathrm{mEq} / \mathrm{min}$. during the entire investigation. After 4 hours at serum bicarbonate levels of about $25 \mathrm{mEq} / 1$., Tm was measured over three 30-minute periods, after which acetazolamide in a single dose of $25 \mathrm{mg}$. $/ \mathrm{kg}$. was administered intravenously, and collections were continued for a further three 30-minute periods. Curves of bicarbonate reabsorption and excretion were constructed and plotted (Pitts, Ayer, and Schiess, 1949).

\section{Results}

Blood/serum. Hb $10 \cdot 1$ g. $/ 100 \mathrm{ml}$, haematocrit 36\%. Na $139 \mathrm{mEq} / \mathrm{l}$., K $4.3 \mathrm{mEq} / \mathrm{l}$., Cl 121 mEq/1., Ca $9.4 \mathrm{mg} . / 100 \mathrm{ml}$., P $5.1 \mathrm{mg} . / 100 \mathrm{ml}$, pH 7.11, $\mathrm{PCO}_{2} 28.5 \mathrm{~mm}$. Hg, st. $\mathrm{HCO}_{3}^{-} 10 \cdot 4$ mEq/l., total $\mathrm{CO}_{2} 8.6 \mathrm{mEq} / 1$.; urea $38 \mathrm{mg} . / 100 \mathrm{ml}$., creatinine $0.5 \mathrm{mg} . / 100 \mathrm{ml}$. PBI $4.8 \mu \mathrm{g} . / 100 \mathrm{ml}$, cholesterol $162 \mathrm{mg} . / 100 \mathrm{ml}$., alkaline phosphatase 296 I.U.

Immunoglobulins: IgG $871 \mathrm{mg} . / 100 \mathrm{ml} .$, IgA $59 \mathrm{mg} . / 100 \mathrm{ml}$; IgM $70 \mathrm{mg} . / 100 \mathrm{ml}$.

Gastric acid secretion. Free acidity 51-71 $\mu \mathrm{Eq} / \mathrm{ml}$. (normal 15-95); total acidity 78-97 $\mu \mathrm{Eq} /$ ml. (normal 25-105).

Urine. $p \mathrm{H} 5 \cdot 0$, output $300-350 \mathrm{ml} . / 24$ hours; protein nil; culture sterile.

Renal function studies. GFR, calculated from creatinine and inulin clearances, was normal. Maximal concentrating capacity was clearly impaired. Urine osmolality after thirsting: 582 $\mathrm{mOsm} / \mathrm{kg}$. $\mathrm{H}_{2} \mathrm{O}$, after vasopressin: $513 \mathrm{mOsm} / \mathrm{kg}$. $\mathrm{H}_{2} \mathrm{O}$. Reducing substances absent in urine. 
TABLE I

Ammonium Chloride Loading Test

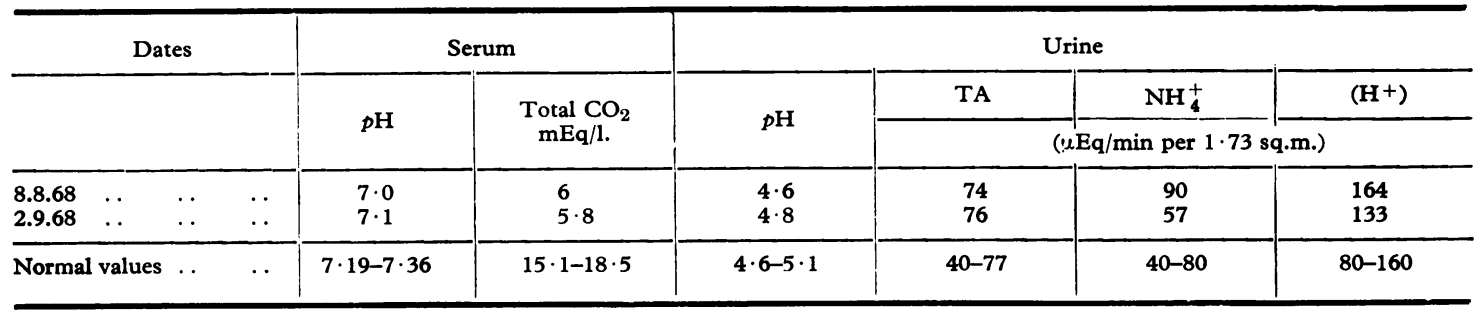

Glucose reabsorption, no glucosuria at serum glucose of $180 \mathrm{mg} . / 100 \mathrm{ml}$.; TmG $370 \mathrm{mg} . / \mathrm{min}$. $1.73 \mathrm{~m}^{2}$. No abnormal aminoaciduria.

Calciuria: $4 \cdot 9,6 \cdot 7$, and $5 \cdot 1 \mathrm{mg} . / \mathrm{kg}$. per 24 hours (normal up to $8 \mathrm{mg}$.). Phosphate reabsorption $80 \%$ (normal 75-95\%).

$\mathrm{NH}_{4} \mathrm{Cl}$ loading test: at serum total $\mathrm{CO}_{2}$ level of $6 \mathrm{mEq} / 1$. , an acid urine was excreted $(\mathrm{pH} \mathrm{4} \cdot 6)$, containing normal amounts of TA and $\mathrm{NH}_{4}^{+}$(serum and urine values three hours after acid loading are presented in Table I).

The hydrogen ion clearance index was abnormally low, $0 \cdot 164 \times 6=0 \cdot 984$ (normal range: $1 \cdot 25-2 \cdot 30$ ).

\section{Bicarbonate loading test.}

(a) Threshold. During the $\mathrm{HCO}_{3}^{-}$loading test, significant bicarbonaturia occurred once the serum total $\mathrm{CO}_{2}$ rose above $10.3 \mathrm{mEq} / \mathrm{l}$. (Fig. 2).

(b) Tm $\mathrm{HCO}_{3}^{-}$. This was determined twice. The low threshold made it difficult to attain high serum levels by the standardized method (Pitts et al., 1949, and Edelmann et al., 1967b).

Serum $\mathrm{HCO}_{3}^{-}$levels attained by means of the

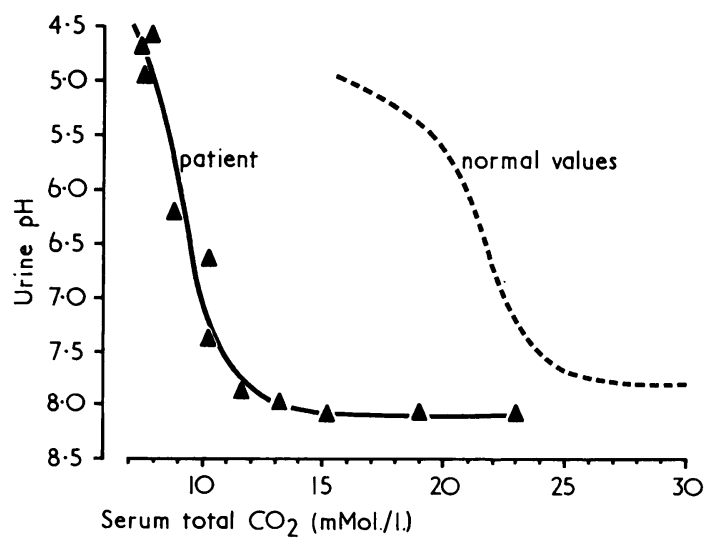

Fig. 2.-Relation between urinary $\mathrm{pH}$ and serum total $\mathrm{CO}_{2}$. standardized method ranged from $18 \cdot 2$ to $20 \cdot 0$ $\mathrm{mEq} / \mathrm{l}$; the corresponding $\mathrm{HCO}_{3}^{-}$reabsorption ranged from 0.93 to $1.09 \mathrm{mEq} / 100 \mathrm{ml}$. GF (Table I; Fig. 3).

In a second investigation (see methods) $\mathrm{Tm}$ was determined at serum $\mathrm{HCO}_{3}^{-}$levels ranging from 25.0 to $27.0 \mathrm{mEq} / \mathrm{l}$; the corresponding $\mathrm{HCO}_{3}^{-}$ reabsorption ranged from 0.94 to $1.15 \mathrm{mEq} /$ $100 \mathrm{ml}$. GF. (Table I).

(c) Acetazolamide effect. The effect of acetazolamide was studied twice (Table II), after the administration of 12.5 and of $25 \mathrm{mg}$. $/ \mathrm{kg}$.; neither was followed by significant change in $\mathrm{HCO}_{3}^{-}$ reabsorption.

\section{Discussion}

Our patient shows dwarfism associated with metabolic acidosis. Studies showed that there was a disturbance of renal acid-base regulation, involving lowered renal threshold for $\mathrm{HCO}_{3}^{-}$, combined with lowered maximum reabsorption capacity for

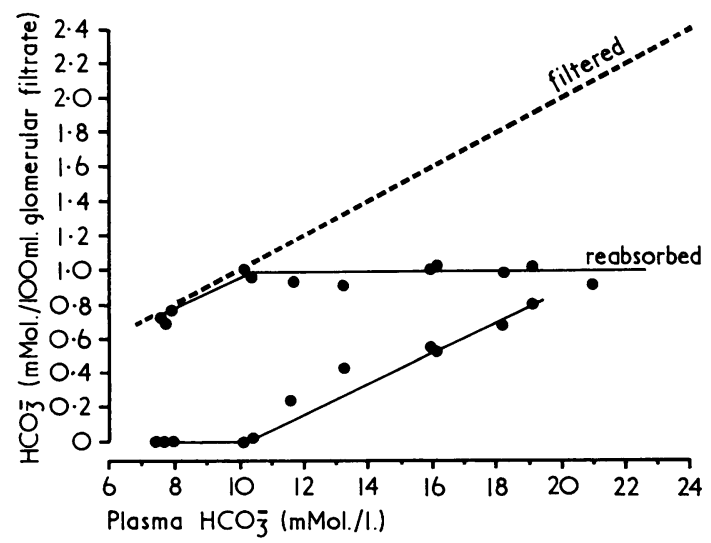

FIG. 3.-Bicarbonate reabsorption and excretion of the patient. The graph shows the $\mathrm{HCO}_{3}^{-}$threshold at $10 \cdot 5$ $\mathrm{mEq} / \mathrm{l}$. and Tm at $1.1 \mathrm{mMol} / 100 \mathrm{ml}$. GF (normal values $\mathrm{HCO}_{3}^{-}$threshold 24-26 mEq/l.; Tm 2.6-2.8 mMoll $100 \mathrm{ml} . \mathrm{GF})$. 
TABLE II

Bicarbonate Reabsorption and Acetazolamide Effect

\begin{tabular}{|c|c|c|c|c|c|c|c|}
\hline \multirow[b]{2}{*}{ Period of Investigation } & \multirow{2}{*}{$\begin{array}{l}\text { Minutes after } \\
\text { Start of } \\
\text { Infusion }\end{array}$} & \multicolumn{2}{|c|}{ Serum } & \multirow[b]{2}{*}{$\begin{array}{l}\text { Diuresis } \\
\text { (ml./min.) }\end{array}$} & \multirow[b]{2}{*}{$\begin{array}{c}\text { GFR } \\
\text { (ml./min.) }\end{array}$} & \multicolumn{2}{|c|}{ Bicarbonate } \\
\hline & & $\underset{(\mathrm{mI}}{\mathrm{HCO}_{3}^{-}}$ & $\mathbf{K}$ & & & $\begin{array}{l}\text { Reabsorption } \\
(\mathrm{mEq} / 100\end{array}$ & $\begin{array}{l}\text { Excretion } \\
\text { nl. GF) }\end{array}$ \\
\hline $\begin{array}{l}\text { First study (see methods) } \\
\mathrm{NaHCO}_{3} 0.45 \mathrm{mEq} / \mathrm{min} . \\
\text { Acetazolomide } 12.5 \mathrm{mg} . / \mathrm{kg} .\end{array}$ & $\begin{array}{l}300-330 \\
331-361 \\
368-398 \\
399-429\end{array}$ & $\begin{array}{l}19 \cdot 1 \\
20 \cdot 0 \\
21 \cdot 0 \\
23 \cdot 0\end{array}$ & $\bar{z}$ & $\begin{array}{l}1 \\
1 \cdot 17 \\
1 \cdot 3 \\
1 \cdot 4\end{array}$ & $\begin{array}{l}22 \cdot 5 \\
23 \cdot 4 \\
22 \cdot 8 \\
23 \cdot 8\end{array}$ & $\begin{array}{l}1 \cdot 09 \\
0 \cdot 93 \\
0 \cdot 93 \\
1 \cdot 06\end{array}$ & $\begin{array}{l}0 \cdot 80 \\
1 \cdot 00 \\
1 \cdot 12 \\
1 \cdot 24\end{array}$ \\
\hline $\begin{array}{l}\text { Second study (see methods) } \\
\mathrm{NaHCO}_{3} 0.45 \mathrm{mEq} . / \mathrm{min} . \\
\text { Acetazolomide } 25 \mathrm{mg} . / \mathrm{kg} .\end{array}$ & $\begin{array}{l}0 \\
241-271 \\
272-302 \\
306 \\
305-335 \\
335-366 \\
367-397\end{array}$ & $\begin{array}{l}26 \cdot 0 \\
27 \cdot 0 \\
35 \cdot 0 \\
33 \cdot 0 \\
30 \cdot 0\end{array}$ & $\begin{array}{l}4 \cdot 3 \\
3 \cdot 5 \\
2 \cdot 1\end{array}$ & $\begin{array}{l}2 \cdot 47 \\
2 \cdot 33 \\
2 \cdot 16 \\
2 \cdot 16 \\
1 \cdot 93\end{array}$ & $\begin{array}{l}20 \cdot 2 \\
18 \\
20 \cdot 0 \\
18 \cdot 7 \\
19\end{array}$ & $\begin{array}{l}1 \cdot 15 \\
0 \cdot 94 \\
1 \cdot 28 \\
1 \cdot 15 \\
1 \cdot 12\end{array}$ & $\begin{array}{l}1 \cdot 14 \\
1 \cdot 70 \\
2 \cdot 22 \\
2 \cdot 05 \\
1 \cdot 88\end{array}$ \\
\hline
\end{tabular}

$\mathrm{HCO}_{3}^{-}$. As the serum $\mathrm{HCO}_{3}^{-}$was below the threshold, the capacity for acid excretion was considered to be normal.

Hydrogen ion excretion, as expressed in terms of its clearance index, was defective. The hydrogen ion clearance index relates urinary acid excretion to serum total $\mathrm{CO}_{2}$. Excretion of acid in response to acid loads however does not depend in the main on changes in plasma bicarbonate (Relman, 1969). This was illustrated by the absence of a linear relation between serum total $\mathrm{CO}_{2}$ and acid excretion over the entire range of total $\mathrm{CO}_{2}$ values (Edelmann et al., 1967c). The $\mathrm{H}+$ clearance index cannot therefore be used to demonstrate impairment of acid excretion in conditions with lowered renal threshold of $\mathrm{HCO}_{3}^{-}$.

Our patient had no significant disturbance of glomerular filtration, nor any systemic disease, and her disorder should thus be classified as a primary bicarbonate wasting renal tubular acidosis.

To investigate the cause of the disturbed bicarbonate reabsorption, the effect of inhibition of renal carboanhydrase was studied by giving acetazolamide intravenously, after normalizing the $\mathrm{HCO}_{3}^{-}$level and correcting the acidosis by continuous intravenous bicarbonate. There was no change in $\mathrm{HCO}_{3}^{-}$ reabsorption. Bicarbonate excretion increased in the first study period concomitant with the serum bicarbonate level and without a change in bicarbonate reabsorption. In the second period the increase in bicarbonate excretion and serum level was accompanied by a slight increase in bicarbonate reabsorption.

The effect of acetazolamide on bicarbonate reabsorption is dependent on several factors, such as dosage (Gordon et al., 1960; Schwartz et al., 1958), mode of administration, and degree of acidosis
(Kaye, 1955; Maren, 1956; Schwartz et al., 1958; Webster et al., 1960), and the nature of renal disorder (Kaye, 1955; Rodriguez Soriano et al., 1967; Schwartz et al., 1958; Yaffe, Craig, and Fellers, 1960). Our study was carried out at a blood $p \mathrm{H}$ of $7 \cdot 40$ and 7.44, a $\mathrm{PCO}_{2}$ of 30 and $36 \mathrm{~mm}$. $\mathrm{Hg}$, and a serum total $\mathrm{CO}_{2}$ of 20.0 and $35.0 \mathrm{mEq} / \mathrm{l}$. The doses administered fall within the effective range indicated by Schwartz et al. (1958), and our patient had no gross reduction in nephron mass. The data obtained in the first part of the study are suggestive of the absence of an acetazolamide effect.

The slight increase in bicarbonate reabsorption in the second part of the study is difficult to interpret and the conditions of the experiment allow no firm conclusion about the presence or absence of an acetazolamide effect.

The absence of any decrease in reabsorption, however, does suggest that acetazolamide was without effect. This absence of an acetazolamide effect may be a consequence of a qualitative carboanhydrase deficiency. Proof of a quantitative deficiency would be obtainable only by an enzymatic study (Yaffe et al., 1960).

The diagnosis of a renal carboanhydrase deficiency raises the question of carboanhydrase acitivity in other body cells; this is often studied by measuring the secretion of gastric acid following histamine stimulation (Hogben, 1960; Rodriguez Soriano et al., 1967). We found that our patient was capable of secreting gastric acid after stimulation. However, little weight should be placed on this finding in relation to a possible deficiency of carboanhydrase in the gastric cells, as the effect of acetazolamide on gastric acid secretion is small (Powell et al., 1962).

Primary bicarbonate-losing renal tubular acidosis 
manifests itself clinically in retardation of growth. Association with ocular lesions has not been previously reported. Biochemically, the dominant feature is hyperchloraemic acidosis. The ability to produce acid urine is unimpeded in rate type RTA, which is further distinguished from gradient type RTA by the absence of abnormal calciuria and of nephrocalcinosis. The basic abnormality in these patients ia a lowered renal threshold for $\mathrm{HCO}_{3}^{-}$, some patients show a lowered $\mathrm{Tm} \mathrm{HCO}_{3}^{-}$as well. Once the serum $\mathrm{HCO}_{3}^{-}$is brought below the thres. hold, they are capable of excreting acid urine and producing adequate amounts of $\mathrm{TA}$ and $\mathrm{NH}_{4}^{+}$.

The aetiology of the disease has so far remained obscure. Bicarbonate reabsorption involves three different mechanisms: (a) carboanhydrase dependent hydration of $\mathrm{CO}_{2}$; (b) $\mathrm{CO}_{2}$-dependent, but noncatalysed hydration of $\mathrm{CO}_{2}$; and (c) direct reabsorption of $\mathrm{HCO}_{3}^{-}$as such (Gordon et al., 1960; Hanley et al., 1959; Rector, Carter, and Seldin, 1965; Schwartz et al., 1958). The data collected in this study suggest a defect in the first mechanism as a probable cause of the disease in our patient.

This study was made possible by the assistance of sister $\mathrm{H}$. W. van der Meulen and by the analytical work of $M$. E. Krom and her staff of laboratory technicians. The patient was referred to us by Dr. F. A. Rive.

\section{REFERENCES}

Edelmann, C. M., Jr., Barnett, H. L., Stark, H., Boichis, H., and Rodriguez Soriano, J. (1967a). A standardized test of renal concentrating capacity in children. American fournal of Diseases of Children, 114, 639.

- Boichis, H., Rodriguez Soriano, J., and Stark, H. (1967b) The renal response of children to acute ammonium chloride acidosis. Pediatric Research, 1, 452.

_- Rodriguez Soriano, J., Boichis, H., Gruskin, A. B., and Acosta, M. I. (1967c). Renal bicarbonate reabsorption and hydrogen ion excretion in normal infants. Fournal of Clinical Investigation 46, 1309.

Elkinton, J. R., Huth, E. J., Webster, G. D., Jr., and McCance, R. A. (1960). The renal excretion of hydrogen ion in renal tubular acidosis. I. Quantitative assessment of the response to ammonium chloride as an acid load. American fournal of Medicine, 29, 554.

Gordon, G. B., Eichenholz, A., MacDonald, F. M., and Semba, T. T. (1960). Studies on the mechanism of bicarbonate reabsorption in man. Fournal of Laboratory Clinical and Medicine, 56, 294.

Hanley, T., Jowett, G. H., Kilpatrick, R., and Platts, M. M. (1959). The role of carbonic anhydrase in renal reabsorption of bicarbonate. Fournal of Physiology, 145, 277.

Hogben, C. A. M. (1960). Formation of hydrochloric acid by the stomach. American fournal of Medicine, 29, 726.
Kaye, M. (1955). The effect of a single oral dose of the carbonic anhydrase inhibitor, acetazoleamide, in renal disease. fournal of Clinical Investigation, 34, 277.

Maren, T. H. (1956). Carbonic anhydrase inhibition. IV. The effects of metabolic acidosis on the response to Diamox. Bulletin of the fohns Hopkins Hospital, 98, 159.

Mook, H. W. (1930). Een eenvoudig microtoestel voor bepaling van de alkalireserve. Nederlandsch Tijdschrift voor Geneeskunde, 74, 1338.

Morris, R. C., Jr. (1969). Renal tubular acidosis. Mechanisms, Classification and implications. New England fournal of Medicine, 281, 1405.

Oetliker, O., and Rossi, E. (1969). The influence of extracellular fluid volume on the renal bicarbonate threshold. A study of two children with Lowe's Syndrome. Pediatric Research, 3, 140.

Peonides, A., Levin, B., and Young, W. F. (1965). The renal excretion of hydrogen ions in infants and children. Archives of Disease in Childhood, 40, 33.

Pitts, R. F., Ayer, J. L., and Schiess, W. A. (1949). The renal regulation of acid base balance in man. III. The reabsorption and excretion of bicarbonate. Fournal of Clinical Investigation, 28, 35 .

Powell, D. W., Robbins, R. C., Boyett, J. D., and Hirschowitz, B. I. (1962). Evaluation of the gastric $\mathrm{Na}: \mathrm{H}$ exchange mechanism using histamine and diamox. American fournal of Physiology, 202, 293.

Rector, F. C., Jr., Carter, N. W., and Seldin, D. W. (1965). The mechanism of bicarbonate reabsorption in the proximal and distal tubules of the kidney. Fournal of Clinical Investigation, 44, 278.

—, Seldin, D. W., Roberts, A. D., Jr., and Smith, J. S. (1960). The role of plasma $\mathrm{CO}_{2}$ tension and carbonic anhydrase activity in the renal reabsorption of bicarbonate. Fournal of Clinical Investigation, 39, 1706.

Relman, A. S. (1969). The control of acid secretion. Abstracts of the IV th International Congress of Nephrology, Stockholm, p. 96.

Rodriguez Soriano, J., Boichis, H., Stark, H., and Edelmann, C. M. Jr. (1967). Proximal renal tubular acidosis. A defect in bicarbonate reabsorption with normal urinary acidification. Pediatric Research, 1, 81.

- and Edelmann, C. M., Jr. (1969). Renal tubular acidosis. Annual Review of Medicine, 20, 363.

Royer, P., and Broyer, M. (1967). L'acidose rénale au cours des tubulopathies congénitales. Actualités néphrologiques de l'hopital Necker.

—, Mathieu, H. and Habib, R., (1963). Réabsorption tubulaire du glucose. In Problèmes Actuels de Néphrologie infantile p. 15. Flammarion, Paris.

Schwartz, W. B., Falbriard, A., and Relman, A. S. (1958), An analysis of bicarbonate reabsorption during partial inhibition of carbonic anhydrase. Fournal of Clinical Investigation, 37, 744.

van Slyke, D. D., and Neill, J. M. (1924). The determination of gases in blood and other solutions by vacuum extraction and manometric measurement. Fournal of Biological Chemistry. 61, 523.

Webster, G. D., Jr., Huth, E. J., Elkinton, J. R., and McCance, R. A. (1960). The renal excretion of hydrogen ion in renal tubular acidosis. II. Quantitative response to the carbonic anhydrase inhibitor, acetazolamide. American fournal of Medicine, 29, 576.

Yaffe, S. J., Craig, J. M., and Fellers, F. X. (1960). Studies on renal enzymes in a patient with renal tubular acidosis. American fournal of Medicine, 29, 168.

Correspondence to Professor H. A. Tiddens, Wilhelmina Kinderziekenhuis, University Children's Hospital, Utrecht, The Netherlands. 